\title{
Effects of Nimodipine and Nigella sativa on Oxidative Stress and Apoptosis in Serum and Brain Tissue of Rats with Experimental Head Trauma
} \author{
Adnan $\mathrm{EKINCl}^{4}$, Adnan $\mathrm{CEVIZ}^{5}$ \\ ${ }^{1}$ Hitit University, School of Medicine, Department of Neurosurgery, Corum, Turkey \\ ${ }^{2}$ Kirikkale University, School of Medicine, Department of Neurosurgery, Kirikkale, Turkey \\ ${ }^{3}$ Dicle University, School of Medicine, Department of Pathology, Diyarbakir, Turkey \\ ${ }^{4}$ Hitit University, School of Medicine, Department of Otolaryngology, Corum, Turkey \\ ${ }^{5}$ Dicle University, School of Medicine, Department of Neurosurgery, Diyarbakir, Turkey
}

Kagan KAMASAK ${ }^{1}$, Kagan BASARSLAN ${ }^{1}$, Ahmet Turan DAGLI ${ }^{1}$, Mustafa OGDEN ${ }^{2}$, Ulas ALABALIK ${ }^{3}$,

Corresponding author: Kagan KAMASAK drkaankamasak@hotmail.com

\section{ABSTRACT}

AIM: To investigate whether Nimodipine (N) and Nigella sativa (NS) oil have protective, antioxidant effects in brain injury caused by experimental head trauma.

MATERIAL and METHODS: Fifty albino Wistar rats were randomly divided into 5 groups that underwent experimental head trauma. Oxidative parameters were compared in the serum and brain tissue of the different groups. In addition, apoptosis and caspase-3 immunoreactivity were evaluated by histopathological examination.

RESULTS: Serum total antioxidant status (TAS) levels were significantly increased in N and N+NS groups when compared with controls $(p=0.001, p<0.01)$. Tissue TAS levels were significantly higher in the $N S$ and $N+N S$ groups compared to controls $(p=0.001$, $p<0.01$ ). Total oxidant status levels in the brain tissue were significantly higher in the NS group than in the control group ( $p=0.021)$.

CONCLUSION: $\mathrm{N}$ and NS were shown to significantly reduce the occurrence of oxidative stress in secondary brain injury due to head trauma. We also found that apoptosis levels decreased in response to N, NS and N+NS treatments after head trauma.

KEYWORDS: Craniocerebral trauma, Nigella sativa, Nimodipine, Oxidative stress, Apoptosis, Rats

\section{INTRODUCTION}

$\mathrm{H}$ ead trauma is among the most important health issues contributing to death and disability, requiring long-term treatment and care. Approximately $85 \%$ of deaths from traffic accidents are due to traumatic brain injury. In primary damage due to head trauma, brain tissue integrity is impaired, and damage to the vessels, neurons and axonal structures occurs. Secondary damage consists of a chain of biochemical events in response to the primary damage occurring after the initial event $(4,33)$. Since primary tissue damage caused by mechanical head trauma is irreversible, the primary purpose of treatment should be to prevent or eliminate secondary brain damage caused by biochemical or physiological events occurring after the trauma. Secondary damage results in excitotoxicity, ionic imbalance, ATP depletion, proteolysis, and oxidative stress due to the transient release of a large number of excitatory neurotransmitters $(3,42)$.

Brain tissue contains high quantities of polyunsaturated fatty acids; therefore, it is highly vulnerable to reactive oxygen species (ROS) and lipid peroxidation, leading to
Kagan KAMASAK (10): 0000-0002-0404-9667

Kagan BASARSLAN (D) : 0000-0003-2708-450X

Ahmet Turan DAGLI (D) : 0000-0002-9214-8138
Mustafa OGDEN (10): 0000-0002-7129-0936

Ulas ALABALIK (10): 0000-0003-4551-8439

Adnan EKINCI (1) : 0000-0001-7725-8024
Adnan CEVIZ (1) : 0000-0002-0876-6612 
Kamasak K. et al: Nimodipine, Nigella sativa and Head Trauma

neurodegeneration (12). There is a direct relationship between the degree of oxidative stress and brain damage (40). ROS products cause the deterioration of lipids, proteins, and nucleic acids in brain tissue $(1,37,41)$. Antioxidants protect the brain against oxidative damage through enzymatic or nonenzymatic means (38). Catalase, superoxide dismutase (SOD), glutathione peroxidase (Gpx), and paraoxonase (PON1) are among the enzymes involved in the defense against oxygen radicals $(6,8)$.

Under normal conditions, there is a balance between antioxidant defense mechanisms and free radicals, and oxidative stress is observed if this balance becomes impaired in favor of free radicals. Oxidant and antioxidant molecules can be individually measured in the plasma, but recently, total oxidant status (TOS) and total antioxidant status (TAS) measurements have improved $(13,14)$. ROS are highly reactive and attack biomolecules, such as proteins, DNA, and polyunsaturated fatty acids in their environment. Arachidonic acid, a common unsaturated fatty acid, ultimately peroxidizes to form malondialdehyde (MDA) (44).

Many previous studies have examined various agents, such as N, Citicoline, propofol, halothane, isoflurane, Naringin, Erythropoietin and Thimokinone, for their neuroprotective effects due to their ability to inhibit antioxidant and free radical formation $(2,15,19,21,22,23,35,39,43,45,46)$. SOD forms the first line of defense against ROS. SOD is an enzymatic antioxidant that catalyzes the superoxide radical $\left(\mathrm{O}_{2}\right)$, hydrogen peroxide $\left(\mathrm{H}_{2} \mathrm{O}_{2}\right)$, and molecular oxygen $\left(\mathrm{O}_{2}\right)(16)$. Gpx is found in the cytoplasm of cells and protects them against oxidative damage by preventing the formation of $\mathrm{OH}$ from $\mathrm{H}_{2} \mathrm{O}_{2}$ (18). PON1 is an ester hydrolase associated with high-density lipoproteins (HDL) that can hydrolyze paraoxon, a strong inhibitor of cholinesterases (9). NS, in the Ranunculaceae family, has been widely used in the treatment of many diseases in Eastern Mediterranean countries for some time. Despite the 12 known species of Nigella species growing in Turkey, only NS can be cultivated $(30,31)$.

NS consists of volatile oils, $0.4 \%$ to $0.45 \%, 18.4 \%$ to $24 \%$, and $45 \%$ to monoterpenes (10). Many studies have shown that NS is a bronchodilator, immunomodulator, antibacterial, hypotensive, antidiabetic, hepatoprotective, gastroprotective, antihistamine, antioxidative and neuroprotective compound $(10,11,20,23-29,47)$.

Nimodipine is an L-type calcium channel blocker, which is known to increase cerebral blood flow in humans and animals by expanding cerebral arterioles. Apoptosis is a physiological event also known as cell suicide. After receiving signals for apoptosis, many biochemical events (DNA fragmentation, excretion of phosphatidylserine molecules on the outer surface of the cell membrane) and morphological changes (cell shrinkage, chromatin condensation and apoptotic body formation) occur within the cell (17).

In our study, we assessed SOD, GPx, PON1, MDA, TOS and TAS levels in brain tissue and serum after experimental head trauma in rats administered Nimodipine and NS. Apoptosis and caspase- 3 immunoreactivity were also compared among groups by histopathological examination. We aimed to investigate the effects of Nand NS on oxidative stress and brain injury in rats after experimental head trauma.

\section{MATERIAL and METHODS}

Ethics approval for this study was obtained from the Dicle University Animal Experiments Local Ethics Committee. The study was performed at the Dicle University Medical Faculty's Experimental and Clinical Research Center between 29/04/2010 and 29/04/2011. All experimental, surgical and laboratory studies were performed at the Dicle University Experimental Research Centre, Dicle University Medical Faculty Biochemistry and Pathology Laboratories.

\section{Experimental materials and laboratory environment}

Fifty male Wistar albino rats weighing 250-340 g were used in the study. Rats were housed in groups of two or three in wire cages under standard laboratory conditions $\left(23 \pm 3^{\circ} \mathrm{C}\right.$ in a 12 hours light/dark cycle). Animals were fed a standard pellet diet and water. Rats suspected of having an underlying disease were not included in the experiments. Through a simple random sampling method, rats were divided into five groups, with ten rats per group.

\section{Surgical procedures and experimental protocols}

Experimental groups were organized as follows:

Control Group (C): Head trauma was not induced, and intrathecal saline was administered.

Head Trauma Group (HT): Experimental head trauma was induced, and no medication was given.

Nimotidipine Group (N): Experimental head trauma was induced, and $\mathrm{N}$ was administered subcutaneously at a dose of $50 \mathrm{mg} / \mathrm{kg}$ twice at 12-hour intervals.

Nigella sativa Group (NS): Experimental head trauma was induced, and NS was administered orally at $400 \mathrm{mg} / \mathrm{kg}$ by intragastric intubation 1 day before trauma.

Nimodipine + Nigella sativa Group $(\mathrm{N}+\mathrm{NS})$ : Experimental head trauma was induced, and $\mathrm{N}$ and NS were administered together at the previously mentioned dosages and times.

\section{Head Trauma Model}

In this study, the weight drop method, developed by Marmarou et al., was used to induce head trauma (32). Rats were sacrificed 24 hours after the induction of head trauma. Before any experimental surgical procedures, anesthesia was administered with $75 \mathrm{mg} / \mathrm{kg}$ intramuscular ketamine hydrochloride (Ketalar 500 mg; Pfizer, Istanbul, Turkey) and 10 $\mathrm{mg} / \mathrm{kg}$ xylazine hydrochloride (Rompun 2\%; Bayer, Istanbul, Turkey). Some of the samples were separated for biochemical examination, and others were fixed in 10\% buffered formalin solution for histopathological examination.

\section{Histopathology:}

Tissue samples for histopathological evaluation were fixed in $10 \%$ formaldehyde solution for 24 hours. Samples were 
evaluated by the same pathologist under light microscopy, and apoptosis levels were assessed in brain tissue. In addition, Hematoxylin Eosin (HE) and caspase 3 staining were used to identify apoptosis. Apoptotic cells were evaluated according to nuclear morphology and stained with hematoxylin in $\mathrm{HE}$ staining. Observable changes included cell shrinkage or cytoplasmic shrinkage, chromatin condensation, and the reduction or division of the nucleus (17). Active caspase-3 method was detected by immunohistochemical staining in apoptotic cells. For this measurement, to determine whether the tissue expresses caspase-3 or the agent that causes apoptosis in the treated tissue induces caspase-3, $\mathrm{T}$ immunoperoxidase immunohistochemical staining was observed in apoptotic cells (36).

\section{Biochemical Analyses}

Brain tissue was frozen at $-80^{\circ} \mathrm{C}$ immediately after removal. Then, after being separated into small pieces, tissue was homogenized using 1/5 (w/v) phosphate solution. Samples were centrifuged for $10 \mathrm{~min}$ at $4000 \mathrm{rpm}$, and serum was separated and stored at $-80^{\circ} \mathrm{C}$ until analysis. For TAS and TOS analyses, the method developed by Erel was used. For this purpose, a completely automated RelAssay kit (Rel Assay Diagnostics kit, Mega Tip, Gaziantep, Turkey) was used with the colorimetric method using the VitalScientific, Selectra/ Flexor E (The Netherlands) autoanalyzer. TAS and TOS results are presented as $\mu \mathrm{mol} \mathrm{H}_{2} \mathrm{O}_{2}$ equivalent/L $(13,14)$. In the samples, MDA was measured according to the method of Draper and Hadley. The principle of this method is based on the spectrophotometric measurement of pink color absorbance resulting from the thiobarbituric acid (TBA) reaction with MDA (7). Spectrophotometric measurements were performed on the Perkin Elmer Lambda 20 UV/VIS spectrometer (Lake Michigan Computers, Saint Joseph, Michigan, USA). The results are shown as nmol/g protein. PON1 levels were measured using a fully automatic RelAssay ${ }^{\circledR}$ (RelAssay Diagnostics kit, Mega Tıp, Gaziantep, Turkey) commercial kit in an Abbott Architect ${ }^{\circledR}$ c16000 autoanalyzer. The results are shown as units $/ \mathrm{mol}$. In tris buffer, the calcium ion-activated PON1 enzyme catalyzes paraoxane into p-nitrofenole (diethyl-p-nitrophenylphosphate). The molar absorbance of P-nitrofenole is $18.290 \mathrm{M}-1 \mathrm{~cm}$ 1 , and one unit of PON1 activity equals $1 \mathrm{~mol}$ of product generated in $1 \mathrm{~min}$ at $37^{\circ} \mathrm{C}$. The results are shown as units/ mol. For assessment of SOD, a kit was utilized and measured by ELISA (Cayman Chemicals, Ann Arbor, MI, USA). The results are shown as $\mathrm{U} / \mathrm{g}$ protein.

\section{Statistical Analysis}

Data were analyzed using Statistical Packages for the Social Sciences (version 22.0, SPSS Inc, Chicago, IL). Descriptive statistics are presented as the mean \pm standard deviation and median (min-max) values. Significance between difference groups was evaluated using the Kruskal-Wallis test (nonparametric analysis of variance) because data did not meet the assumptions of the parametric test analysis of variance. Post hoc pairwise comparison tests were used to determine which groups differed significantly. A p-value $<0.05$ was considered statistically significant.

\section{RESULTS}

\section{TAS}

Serum TAS levels were significantly higher in NS and $\mathrm{N}+\mathrm{NS}$ groups compared to controls $(p=0.001, p<0.01)$. The mean serum TAS levels were $0.04 \pm 0.03 \mathrm{mmol} / \mathrm{L}$ in the Control group, $0.26 \pm 0.13 \mathrm{mmol} / \mathrm{L}$ in the HT group, $0.28 \pm 0.63 \mathrm{mmol} / \mathrm{L}$ in the $\mathrm{N}$ group, $0.45 \pm 0.39 \mathrm{mmol} / \mathrm{L}$ in the NS group and 0.52 $\pm 0.67 \mathrm{mmol} / \mathrm{L}$ in the $\mathrm{N}+\mathrm{NS}$ group (Table I, Figure 1A). In brain tissue, TAS levels were higher in NS and $\mathrm{N}+\mathrm{NS}$ groups than in controls $(p=0.001, p<0.01)$. In the $N$ group, TAS levels were lower than in the control group $(p=0.001)$. The mean tissue serum TAS levels were $0.03 \pm 0.26 \mathrm{mmol} / \mathrm{L}$ in the $\mathrm{C}$ group, $0.20 \pm 0.98 \mathrm{mmol} / \mathrm{L}$ in the HT group, $0.22 \pm 0.05 \mathrm{mmol} / \mathrm{L}$ in the $\mathrm{N}$ group, $0.36 \pm 0.31 \mathrm{mmol} / \mathrm{L}$ in the NS group, and $0.41 \pm 0.05$ $\mathrm{mmol} / \mathrm{L}$ in the $\mathrm{N}+\mathrm{NS}$ group (Table II, Figure 2A).

\section{TOS}

There were no significant differences in serum TOS levels between any groups $(p=0.154)$. The mean serum TOS levels were $34.27 \pm 11.29 \mathrm{mmol} / \mathrm{L}$ in the $\mathrm{C}$ group, $28.45 \pm 1.15$ $\mathrm{mmol} / \mathrm{L}$ in the HT group, $31.44 \pm 8.09 \mathrm{mmol} / \mathrm{L}$ in the $\mathrm{N}$ group, $26.09 \pm 7.09 \mathrm{mmol} / \mathrm{L}$ in the NS group, and $25.17 \pm 12.28$ $\mathrm{mmol} / \mathrm{L}$ in the $\mathrm{N}+\mathrm{NS}$ group (Table I, Figure 1B). TOS levels in the brain were significantly higher in the NS group than in the control group $(p=0.021)$. The mean tissue serum TOS levels were $122.85 \pm 40.47 \mathrm{mmol} / \mathrm{L}$ in the $\mathrm{C}$ group, $101.98 \pm 4.14$ $\mathrm{mmol} / \mathrm{L}$ in the HT group, $92.75 \pm 23.89 \mathrm{mmol} / \mathrm{L}$ in the $\mathrm{N}$ group, $76.97 \pm 20.91 \mathrm{mmol} / \mathrm{L}$ in the NS group and $74.26 \pm 36.24$ $\mathrm{mmol} / \mathrm{L}$ in the $\mathrm{N}+\mathrm{NS}$ group (Table II, Figure $2 \mathrm{~B}$ ).

\section{GPx}

There was no significant difference in the serum GPx levels between groups $(p=0.090)$. The mean serum GPx levels were $104.34 \pm 37.76 \mathrm{mmol}$ in the $\mathrm{C}$ group, $122.17 \pm 18.94 \mathrm{mmol}$ in the HT group, $91.83 \pm 35.97 \mathrm{mmol}$ in the $\mathrm{N}$ group, 85.57 $\pm 31.67 \mathrm{mmol}$ in the NS group and $89.10 \pm 36.50 \mathrm{mmol}$ in the $\mathrm{N}+\mathrm{NS}$ group (Table I, Figure 1C). There was no significant difference in the brain tissue GPx levels between groups $(p=0.034)$. The mean tissue serum GPx levels were $163.80 \pm$ $59.28 \mathrm{mmol}$ in the $\mathrm{C}$ group, $191.80 \pm 29.73 \mathrm{mmol}$ in the HT group, $133.87 \pm 52.44 \mathrm{mmol}$ in the $\mathrm{N}$ group, $124.74 \pm 46.17$ $\mathrm{mmol}$ in the NS group and $129.88 \pm 53.20 \mathrm{mmol}$ in the $\mathrm{N}+\mathrm{NS}$ group (Table II, Figure 2C).

\section{MDA}

There was a statistically significant difference in MDA levels between groups in both brain tissue and serum $(p<0.001)$. MDA levels were reduced in $\mathrm{N}$ and $\mathrm{N}+\mathrm{NS}$ groups compared to controls $(p<0.001, p=0.001)$. MDA levels were significantly lower in N, NS, and N + NS groups compared to the CT group $(p=0.002, p=0.004, p=0.014)$. The mean serum MDA level was $37.20 \pm 8.92 \mathrm{mmol}$ in the $\mathrm{C}$ group, $33.79 \pm 13.65 \mathrm{mmol}$ in the HT group, $15.97 \pm 2.1 \mathrm{mmol}$ in the $\mathrm{N}$ group, $16.73 \pm 2.43$ $\mathrm{mmol}$ in the NS group and $16.84 \pm 3.17 \mathrm{mmol}$ in the $\mathrm{N}+\mathrm{NS}$ group (Table I, Figure 1D). Tissue MDA levels were significantly higher in N, NS, and $\mathrm{N}+\mathrm{NS}$ groups than in the control group $(p=0.001, p=0.001, p=0.011)$. In addition, MDA levels were higher in the $\mathrm{N}$ group compared to the HT group $(p=0.032)$. 


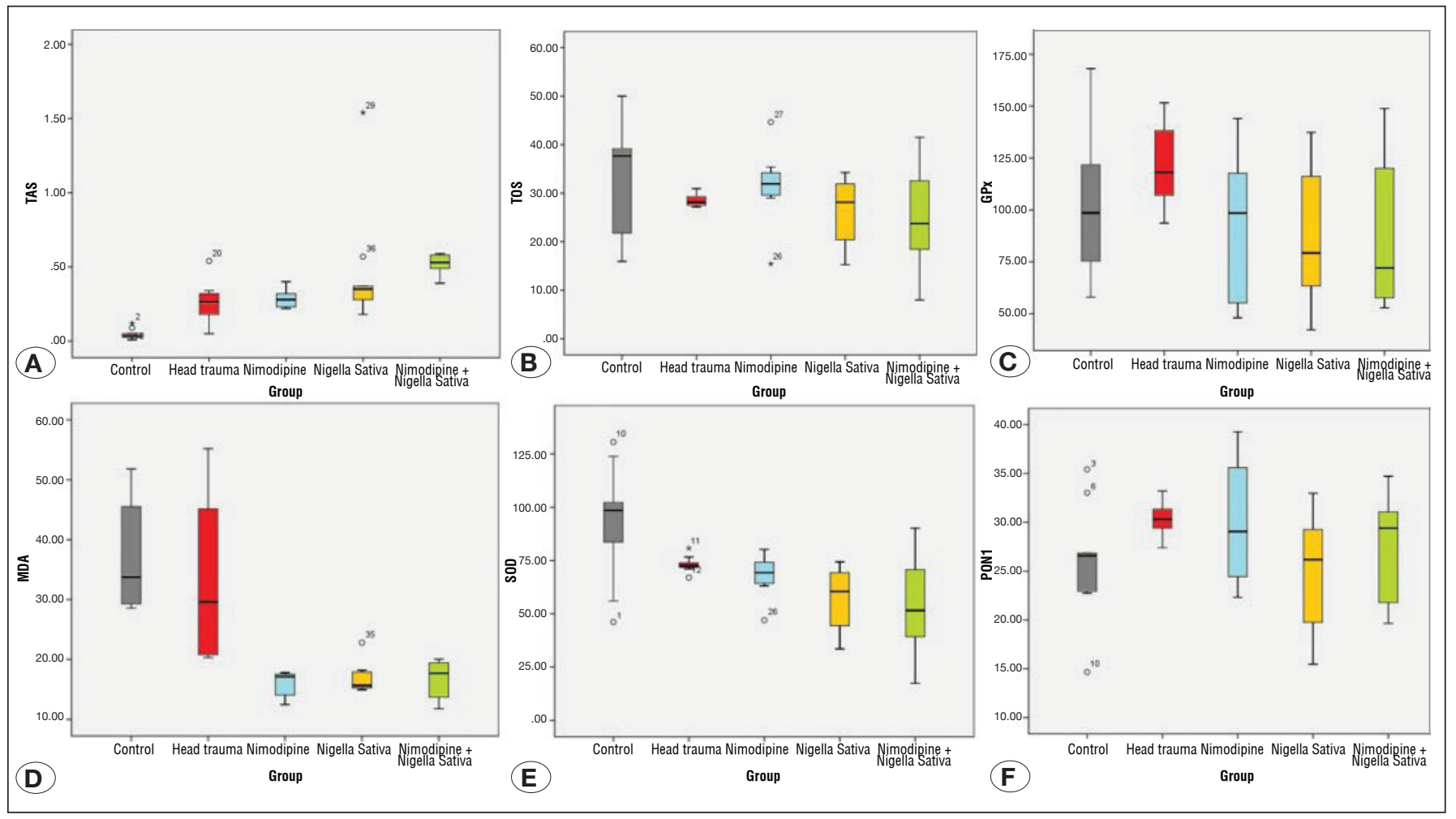

Figure 1: Box plot graphs of TAS, TOS, GPx, MDA, SOD and PON1 levels in serum are shown.

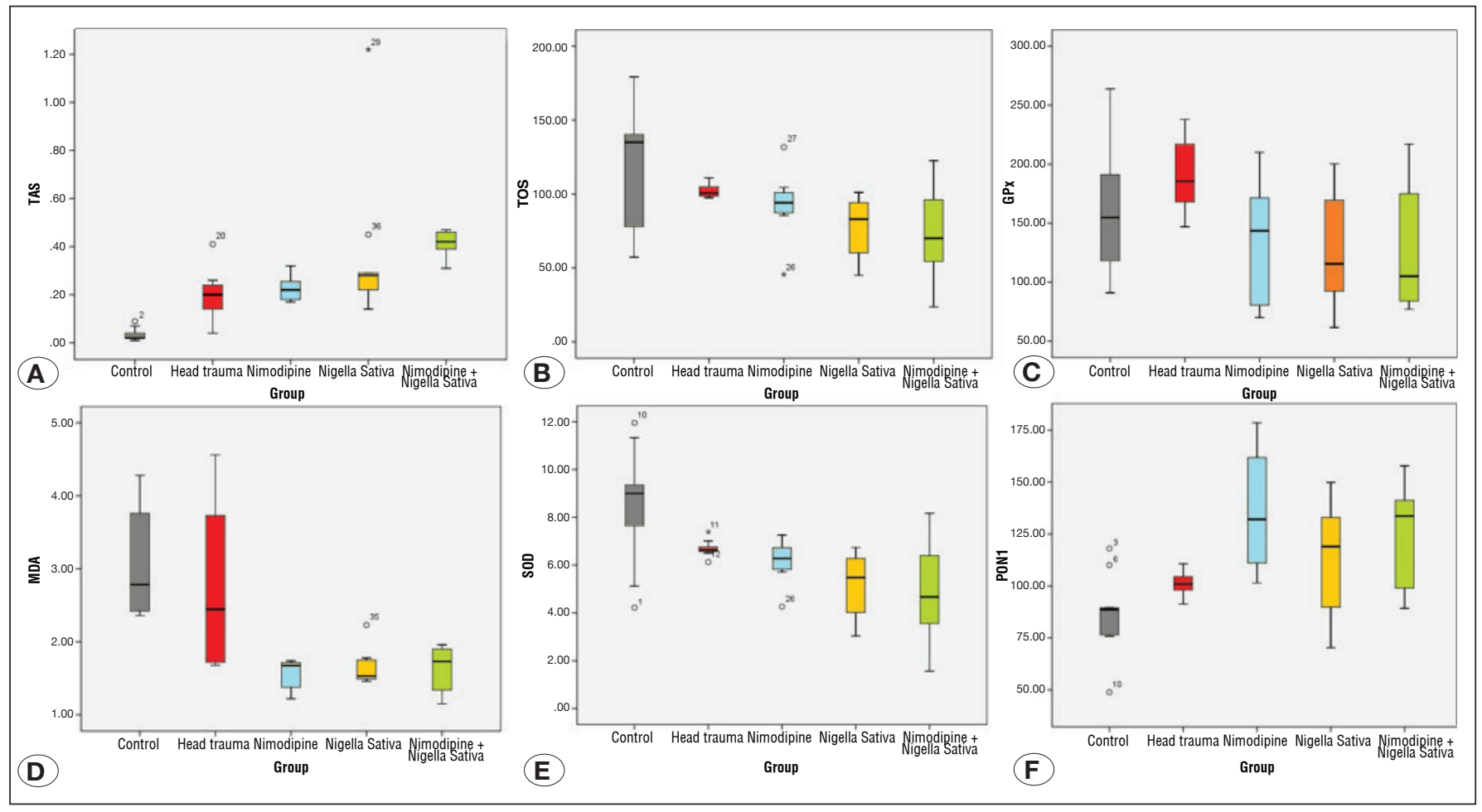

Figure 2: Box plot graphs of TAS, TOS, GPx, MDA, SOD and PON1 levels in tissue. 
The mean tissue serum MDA level was $3.07 \pm 0.73 \mathrm{mmol}$ in the $\mathrm{C}$ group, $2.79 \pm 1.12 \mathrm{mmol}$ in the HT group, $1.56 \pm 0.20$ $\mathrm{mmol}$ in the $\mathrm{N}$ group, $1.63 \pm 0.23 \mathrm{mmol}$ in the NS group and $1.64 \pm 0.30 \mathrm{mmol}$ in the $\mathrm{N}+\mathrm{NS}$ group (Table II, Figure 2D).

\section{SOD}

There was a statistically significant difference between groups in SOD levels in both brain tissue and serum $(p<0.05)$. The mean serum SOD level was $92.65 \pm 26.45 \mathrm{mmol}$ in the $\mathrm{C}$ group, $73.16 \pm 3.62 \mathrm{mmol}$ in the HT group, $67.86 \pm 10.16 \mathrm{mmol}$ in the $\mathrm{N}$ group, $57.02 \pm 15.10 \mathrm{mmol}$ in the NS group and $54.53 \pm$ $26.52 \mathrm{mmol}$ in the $\mathrm{N}+\mathrm{NS}$ group. SOD levels were significantly lower in $\mathrm{N}$ and $\mathrm{N}+\mathrm{NS}$ groups compared to the control group $(p<0.001, p=0.003)$ (Table I, Figure 1E). The mean tissue SOD values in $\mathrm{N}$ and $\mathrm{N}+\mathrm{NS}$ groups were higher than those in the control group $(p=0.004, p=0.014)$. The mean tissue SOD level

Table I: Mean Comparisons for Serum Biochemical Parameters Between Groups (Kruskal-Wallis Analysis of Variance)

\begin{tabular}{|c|c|c|c|c|c|c|c|c|}
\hline \multicolumn{2}{|c|}{$\begin{array}{l}\text { Biochemical } \\
\text { Parameters Groups }\end{array}$} & \multirow{2}{*}{$\begin{array}{l}\mathbf{n} \\
10\end{array}$} & \multirow{2}{*}{$\begin{array}{l}\text { Mean } \pm \text { SD } \\
0.04 \pm 0.35\end{array}$} & \multirow{2}{*}{$\begin{array}{c}\text { Median } \\
0.03\end{array}$} & \multirow{2}{*}{$\begin{array}{l}\text { Min } \\
0.01 \\
\end{array}$} & \multirow{2}{*}{$\begin{array}{r}\text { Max } \\
0.12 \\
\end{array}$} & \multirow[t]{2}{*}{$p$} & \multirow{2}{*}{$\begin{array}{l}\text { Post-hoc } p \\
1-4: p=0.001\end{array}$} \\
\hline TAS & Control (1) & & & & & & & \\
\hline & HT (2) & 10 & $0.26 \pm 0.13$ & 0.26 & 0.05 & 0.54 & \multirow{4}{*}{$<0.001$} & $1-5: p<0.001$ \\
\hline & $N(3)$ & 10 & $0.28 \pm 0.63$ & 0.28 & 0.22 & 0.40 & & $2-5: p=0.024$ \\
\hline & NS (4) & 10 & $0.45 \pm 0.39$ & 0.35 & 0.18 & 1.54 & & \\
\hline & $\mathrm{N}+\mathrm{NS}(5)$ & 10 & $0.52 \pm 0.67$ & 0.53 & 0.39 & 0.59 & & \\
\hline \multirow[t]{5}{*}{ TOS } & Control & 10 & $34.27 \pm 11.29$ & 37.70 & 15.96 & 50.01 & \multirow{5}{*}{0.154} & \\
\hline & $\mathrm{HT}$ & 10 & $28.45 \pm 1.15$ & 28.06 & 27.19 & 30.93 & & \\
\hline & $\mathrm{N}$ & 10 & $31.44 \pm 8.09$ & 31.91 & 15.44 & 44.67 & & \\
\hline & NS & 10 & $26.09 \pm 7.09$ & 28.13 & 15.26 & 34.27 & & \\
\hline & $\mathrm{N}+\mathrm{NS}$ & 10 & $25.17 \pm 12.28$ & 23.73 & 8.00 & 41.54 & & \\
\hline \multirow[t]{5}{*}{ GPx } & Control & 10 & $104.34 \pm 37.76$ & 98.54 & 57.97 & 168.10 & \multirow{5}{*}{0.090} & \\
\hline & $\mathrm{HT}$ & 10 & $122.17 \pm 18.94$ & 118.16 & 9.64 & 151.61 & & \\
\hline & $\mathrm{N}$ & 10 & $91.83 \pm 35.97$ & 98.44 & 48.02 & 144.06 & & \\
\hline & NS & 10 & $85.57 \pm 31.67$ & 79.23 & 42.26 & 137.34 & & \\
\hline & $\mathrm{N}+\mathrm{NS}$ & 10 & $89.10 \pm 36.50$ & 72.03 & 52.82 & 148.86 & & \\
\hline \multirow[t]{6}{*}{ MDA } & Control & 10 & $37.20 \pm 8.92$ & 33.70 & 28.56 & 51.79 & \multirow{5}{*}{$<0.001$} & 1-3: $p<0.001$ \\
\hline & $\mathrm{HT}$ & 10 & $33.79 \pm 13.65$ & 29.58 & 20.33 & 55.18 & & 1-4: $p=0.001$ \\
\hline & $\mathrm{N}$ & 10 & $15.97 \pm 2.11$ & 17.13 & 12.48 & 17.80 & & $2-3: p=0.002$ \\
\hline & NS & 10 & $16.73 \pm 2.43$ & 15.65 & 14.94 & 22.81 & & $2-4: p=0.004$ \\
\hline & $\mathrm{N}+\mathrm{NS}$ & 10 & $16.84 \pm 3.17$ & 17.70 & 11.76 & 20.05 & & $2-5: p=0.014$ \\
\hline & & & & & & & & $1-5: p=0.003$ \\
\hline \multirow[t]{5}{*}{ SOD } & Control & 10 & $92.65 \pm 26.45$ & 98.49 & 46.13 & 130.64 & \multirow{5}{*}{$<0.001$} & 1-4: $p=0.004$ \\
\hline & $\mathrm{HT}$ & 10 & $73.16 \pm 3.62$ & 72.42 & 67.01 & 80.79 & & $1-5: p=0.015$ \\
\hline & $\mathrm{N}$ & 10 & $67.86 \pm 10.16$ & 69.33 & 47.03 & 80.15 & & \\
\hline & NS & 10 & $57.02 \pm 15.10$ & 60.50 & 33.56 & 74.41 & & \\
\hline & $\mathrm{N}+\mathrm{NS}$ & 10 & $54.53 \pm 26.52$ & 51.53 & 17.33 & 90.20 & & \\
\hline \multirow[t]{5}{*}{ PON 1} & Control & 10 & $25.99 \pm 5.68$ & 26.60 & 14.67 & 35.42 & \multirow{5}{*}{$<0.001$} & 1-2: $p<0.001$ \\
\hline & $\mathrm{HT}$ & 10 & $30.43 \pm 1.67$ & 30.30 & 27.39 & 33.20 & & $1-3: p=0.001$ \\
\hline & $\mathrm{N}$ & 10 & $29.97 \pm 6.35$ & 29.05 & 22.32 & 39.27 & & $1-4: p=0.034$ \\
\hline & NS & 10 & $25.34 \pm 5.71$ & 26.17 & 15.48 & 32.97 & & 1-5: $p=0.004$ \\
\hline & $\mathrm{N}+\mathrm{NS}$ & 10 & $27.44 \pm 5.53$ & 29.44 & 19.64 & 34.72 & & \\
\hline
\end{tabular}

Min: Minimum, Max: Maximum, SD: Standard deviation. C: Control group, HT: Head trauma group, N: Nimodipine group, NS: Nigella Sativa group, N+NS: Nimodipine + Nigella Sativa group. 
was $8.47 \pm 2.42 \mathrm{mmol}$ in the $\mathrm{C}$ group, $6.69 \pm 0.33 \mathrm{mmol}$ in the HT group, $6.47 \pm 0.92 \mathrm{mmol}$ in the $\mathrm{N}$ group, $5.16 \pm 1.36 \mathrm{mmol}$ in the NS group and $4.94 \pm 2.40 \mathrm{mmol}$ in the $\mathrm{N}+\mathrm{NS}$ group (Table II, Figure 2E).

\section{PON1}

Serum PON1 values were significantly different between groups $(p<0.05)$. Serum PON1 levels were significantly reduced in N, NS, and N + NS groups compared to the control group $(p=0,001, p=0.034, p=0.004)$. The mean serum PON1 level was $25.99 \pm 5.68 \mathrm{mmol}$ in the $\mathrm{C}$ group, $30.43 \pm 1.67$ $\mathrm{mmol}$ in the HT group, $29.97 \pm 6.35 \mathrm{mmol}$ in the $\mathrm{N}$ group, $25.34 \pm 5.71 \mathrm{mmol}$ in the NS group and $27.44 \pm 5.53 \mathrm{mmol}$ in the $\mathrm{N}+\mathrm{NS}$ group (Table I, Figure 1F). Tissue PON levels were significantly different between groups in brain tissue $(p<0.05)$. PON1 levels were significantly higher in $\mathrm{N}$ and $\mathrm{N}+\mathrm{NS}$ groups than in controls $(p=0.001, p=0.011)$. The mean tissue PON1 level was $86.65 \pm 18.95 \mathrm{mmol}$ in the $\mathrm{C}$ group, $101.43 \pm 5.58$

Table II: Mean Comparisons for Tissue Biochemical Parameters Between Groups (Kruskal-Wallis Analysis of Variance)

\begin{tabular}{|c|c|c|c|c|c|c|c|c|}
\hline \multicolumn{2}{|c|}{$\begin{array}{l}\text { Biochemical } \\
\text { Parameters Groups }\end{array}$} & \multirow{2}{*}{$\begin{array}{c}\mathbf{n} \\
10 \\
\end{array}$} & \multirow{2}{*}{$\begin{array}{l}\text { Mean } \pm \text { SD } \\
0.03 \pm 0.26\end{array}$} & \multirow{2}{*}{$\begin{array}{r}\text { Median } \\
0.02 \\
\end{array}$} & \multirow{2}{*}{$\begin{array}{l}\text { Min } \\
0.01 \\
\end{array}$} & \multirow{2}{*}{$\begin{array}{r}\text { Max } \\
0.09 \\
\end{array}$} & \multirow[t]{2}{*}{$\mathbf{p}$} & \multirow{2}{*}{$\begin{array}{l}\text { Post-hoc } p \\
1-4: p=0.001\end{array}$} \\
\hline TAS & Control (1) & & & & & & & \\
\hline & HT (2) & 10 & $0.20 \pm 0.98$ & 0.20 & 0.05 & 0.54 & & $1-5: p<0.001$ \\
\hline & ND (3) & 10 & $0.22 \pm 0.52$ & 0.22 & 0.17 & 0.32 & $<0.001$ & $2-5: p=0.018$ \\
\hline & NS (4) & 10 & $0.36 \pm 0.31$ & 0.28 & 0.14 & 1.22 & & \\
\hline & NS+ND (5) & 10 & $0.41 \pm 0.05$ & 0.42 & 0.31 & 0.47 & & \\
\hline \multirow[t]{5}{*}{ TOS } & Control & 10 & $122.85 \pm 40.47$ & 135.12 & 57.21 & 179.25 & & 1-4: $p=0.021$ \\
\hline & $\mathrm{HT}$ & 10 & $101.98 \pm 4.14$ & 100.58 & 97.44 & 110.85 & & \\
\hline & ND & 10 & $92.75 \pm 23.89$ & 94.14 & 0.17 & 0.32 & & \\
\hline & NS & 10 & $76.97 \pm 20.91$ & 83.00 & 0.14 & 1.22 & & \\
\hline & $\mathrm{NS}+\mathrm{ND}$ & 10 & $74.26 \pm 36.24$ & 70.00 & 0.31 & 0.47 & & \\
\hline \multirow[t]{5}{*}{ GPx } & Control & 10 & $163.80 \pm 59.28$ & 154.70 & 91.00 & 263.90 & & \\
\hline & $\mathrm{HD}$ & 10 & $191.80 \pm 29.73$ & 185.50 & 147.00 & 238.00 & & \\
\hline & ND & 10 & $133.87 \pm 52.44$ & 143.50 & 70.00 & 210.00 & & \\
\hline & NS & 10 & $124.70 \pm 46.17$ & 115.50 & 61.60 & 200.20 & & \\
\hline & $\mathrm{NS}+\mathrm{ND}$ & 10 & $129.88 \pm 53.20$ & 105.00 & 77.00 & 217.00 & & \\
\hline \multirow[t]{5}{*}{ MDA } & Control & 10 & $3.07 \pm 0.73$ & 2.78 & 2.36 & 4.28 & & 1-3: $p=0.001$ \\
\hline & $\mathrm{HT}$ & 10 & $2.79 \pm 1.12$ & 2.44 & 1.68 & 4.56 & & 1-4: $p=0.001$ \\
\hline & ND & 10 & $1.56 \pm 0.20$ & 1.67 & 1.22 & 1.74 & & 1-5: $p=0.011$ \\
\hline & NS & 10 & $1.63 \pm 0.23$ & 1.53 & 1.46 & 2.23 & & \\
\hline & $\mathrm{NS}+\mathrm{ND}$ & 10 & $1.64 \pm 0.30$ & 1.73 & 1.15 & 1.96 & & \\
\hline \multirow[t]{5}{*}{ SOD } & Control & 10 & $8.47 \pm 2.42$ & 9.01 & 4.22 & 11.95 & & 1-4: $p=0.004$ \\
\hline & $\mathrm{HT}$ & 10 & $6.69 \pm 0.33$ & 6.62 & 6.13 & 7.39 & & $1-5: p=0.014$ \\
\hline & ND & 10 & $6.14 \pm 0.92$ & 6.28 & 4.26 & 7.26 & & \\
\hline & NS & 10 & $5.16 \pm 1.36$ & 5.48 & 3.04 & 6.74 & & \\
\hline & $N S+N D$ & 10 & $4.94 \pm 2.40$ & 4.67 & 1.57 & 8.17 & & \\
\hline \multirow[t]{5}{*}{ PON 1} & Control & 10 & $86.65 \pm 18.95$ & 88.67 & 48.90 & 118.07 & & 1-3: $p=0.001$ \\
\hline & $\mathrm{HT}$ & 10 & $101.43 \pm 5.87$ & 101.00 & 91.30 & 110.67 & & $1-5: p=0.011$ \\
\hline & ND & 10 & $136.23 \pm 28.88$ & 132.08 & 101.46 & 178.50 & & \\
\hline & NS & 10 & $115.22 \pm 25.96$ & 118.97 & 70.35 & 149.88 & & \\
\hline & $N S+N D$ & 10 & $124.73 \pm 25.17$ & 133.65 & 89.28 & 157.80 & & \\
\hline
\end{tabular}

Min: Minimum, Max: Maximum, SD: Standard deviation. C: Control group, HT: Head trauma group, N: Nimodipine group, NS: Nigella Sativa group, $\mathbf{N + N S : ~ N i m o d i p i n e ~ + ~ N i g e l l a ~ S a t i v a ~ g r o u p . ~}$ 
$\mathrm{mmol}$ in the HT group, $136.23 \pm 28.88 \mathrm{mmol}$ in the $\mathrm{N}$ group, $115.22 \pm 25.96 \mathrm{mmol}$ in the NS group, and $124.73 \pm 25.17$ $\mathrm{mmol}$ in the N+NS group (Table II, Figure 2F).

\section{Histopathological Investigation}

Histopathologically, apoptotic cells were significantly increased in all groups when compared to controls. Compared to the CT group, apoptotic cells were significantly decreased in NS and $\mathrm{N}+\mathrm{NS}$ groups $(\mathrm{p}<0.05)$. There was no statistical significance between the $\mathrm{N}$ and $\mathrm{N}+\mathrm{NS}$ groups. The number of apoptotic cells decreased significantly in the N+NS group compared to the NS group $(p<0.05)$ (Table III). Compared to controls, there was a statistically significant increase in caspase-3 staining in all other groups $(p<0.05)$. The N, NS, and $\mathrm{N}+\mathrm{NS}$ groups exhibited a statistically significant decrease in caspase-3 compared to the CT group $(p<0.05)$. There was also significantly reduced caspase- 3 in the NS and $\mathrm{N}+\mathrm{NS}$ groups compared to the $N$ group $(p<0.05)$. There was no statistically significant difference between the NS and N+NS groups (Table I). Caspase 3 reactivity and apoptotic cell counts for all groups are shown as a box plot in Figure 3. Photomicrographs of HE and immunoperoxidase-stained paraffin sections of rat brain tissue are shown in Figure 4A-K.

\section{DISCUSSION}

In our study, we found that the use of N, NS and N+NS after experimental head trauma reduces oxidative stress products in both serum and brain tissue and decreases the level of apoptosis in brain tissue. When oxidative stress occurs, mitochondrial function may exhibit impaired migration to synaptic regions, resulting in neurons being physically unable perform their normal function $(5,34)$. These physiopathological events explain the development of secondary mechanisms of traumatic brain injury and guide researchers in developing methods to prevent damage by measuring antioxidants, lipid peroxidation products, and protein damage. There are experimental studies showing that oxidative stress and lipid peroxidation occur in brain tissue after head trauma $(43,46)$. The combination of citicoline and propofol prevents the increase in lipid peroxidation and oxidative damage following such head trauma (43). Yurdakoc et al. reported that MDA is a product of lipid peroxidation in response to experimental head trauma, and isoflurane, a general anesthetic, protects against this by decreasing MDA levels (46). Ustun et al. showed that tissue MDA levels in rabbits exposed to head trauma were reportedly higher than those in the controls (45). In our study, we found that MDA levels in brain tissue were significantly higher in N, NS, and N+NS groups than in the control group. In addition, MDA levels in the $\mathrm{N}$ group were higher than those in the HT group. Furthermore, in serum, MDA levels were lower in $\mathrm{N}$ and $\mathrm{N}+\mathrm{NS}$ groups compared to those in the control group. MDA levels in N, NS, and N+NS groups were all significantly lower than those in the CT group.

Neuroprotective drugs are used to combat oxidative damage caused by head trauma. One of these drugs is $\mathrm{N}$, which is used both experimentally and clinically. Animal and human studies have shown that $\mathrm{N}$ increases cerebral blood flow and dilates cerebral arterioles (2). The effect of $\mathrm{N}$ on oxidative stress caused by traumatic brain injury is unclear. In our study, no significant differences were found in TAS, TOS, GPx or PON levels in the brains of rats with induced head injury after $\mathrm{N}$ administration compared to controls. MDA levels in both

Table III: Comparison of Apoptotic Cell Numbers and Caspase 3 Reaction Between Groups (Kruskal-Wallis Analysis of Variance)

\begin{tabular}{|c|c|c|c|c|c|c|}
\hline $\begin{array}{l}\text { Pathological } \\
\text { Parameter Groups }\end{array}$ & $\mathbf{n}$ & Mean \pm SD & Median & Min & Max & $\mathbf{p}$ \\
\hline $\begin{array}{l}\text { Apoptotic cell Count } \\
\text { Control (1) }\end{array}$ & 10 & $0.40 \pm 0.51$ & 0.42 & 0.14 & 0.91 & \multirow{5}{*}{$<0.001$} \\
\hline Head trauma (2) & 10 & $2.8 \pm 0.42$ & 2.7 & 2.37 & 3.22 & \\
\hline Nimodipine (3) & 10 & $2.37 \pm 0.51$ & 2.85 & 1.81 & 2.88 & \\
\hline Nigellasativa (4) & 10 & $1.55 \pm 0.52$ & 1.62 & 1.00 & 2.07 & \\
\hline Nimodipine + Nigella sativa (5) & 10 & $2.22 \pm 0.44$ & 2.19 & 1.78 & 2.66 & \\
\hline
\end{tabular}

Post-hoc p

\begin{tabular}{llllll}
\hline $\begin{array}{l}\text { Caspase 3 } \\
\text { Control }\end{array}$ & 10 & $16.20 \pm 2.89$ & 17.89 & 13.27 & 19.16 \\
\hline Head trauma & 10 & $77.10 \pm 5.13$ & 78.10 & 71.74 & 83.10 \\
\hline Nimodipine & 10 & $59.37 \pm 6.92$ & 62.54 & 52.10 & 66.30 \\
\hline Nigellasativa & 10 & $39.00 \pm 7.50$ & 43.00 & 31.45 & 46.4 \\
\hline Nimodipine + Nigella sativa & 10 & $40.44 \pm 8.38$ & 39.85 & 31.06 & 49.80 \\
\hline
\end{tabular}

1-2: $p=0.010$

1-3: $p=0.015$

1-4: $p<0.001$

1-5: $p=0.001$

4-5: $p<0.001$

2-5: $p<0.001$

1-2: $p=0.001$

1-4: $p<0.001$

1-5: $p<0.001$

2-3: $p=0.002$

2-4: $p=0.001$

2-5: $p<0.001$

Min: Minimum, Max: Maximum, SD: Standard deviation. 


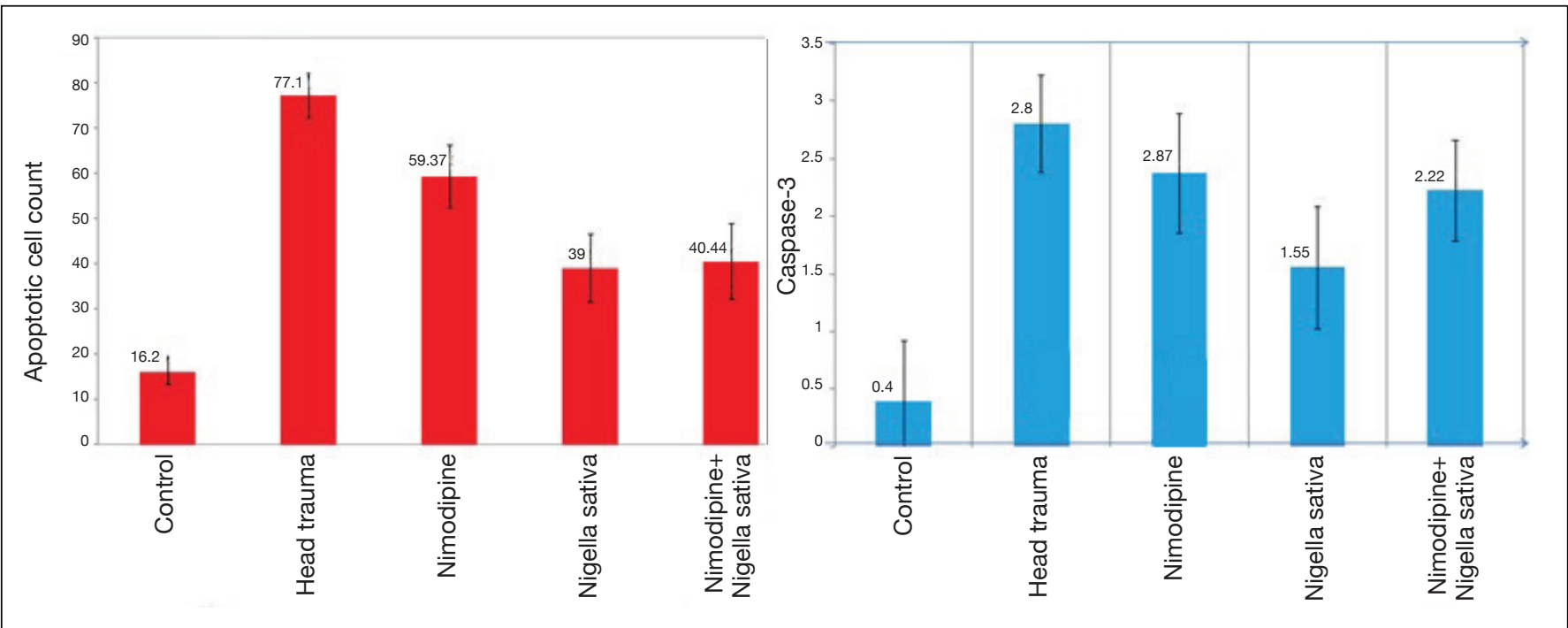

Figure 3: According to groups, caspase-3 reaction and apoptotic cell numbers.

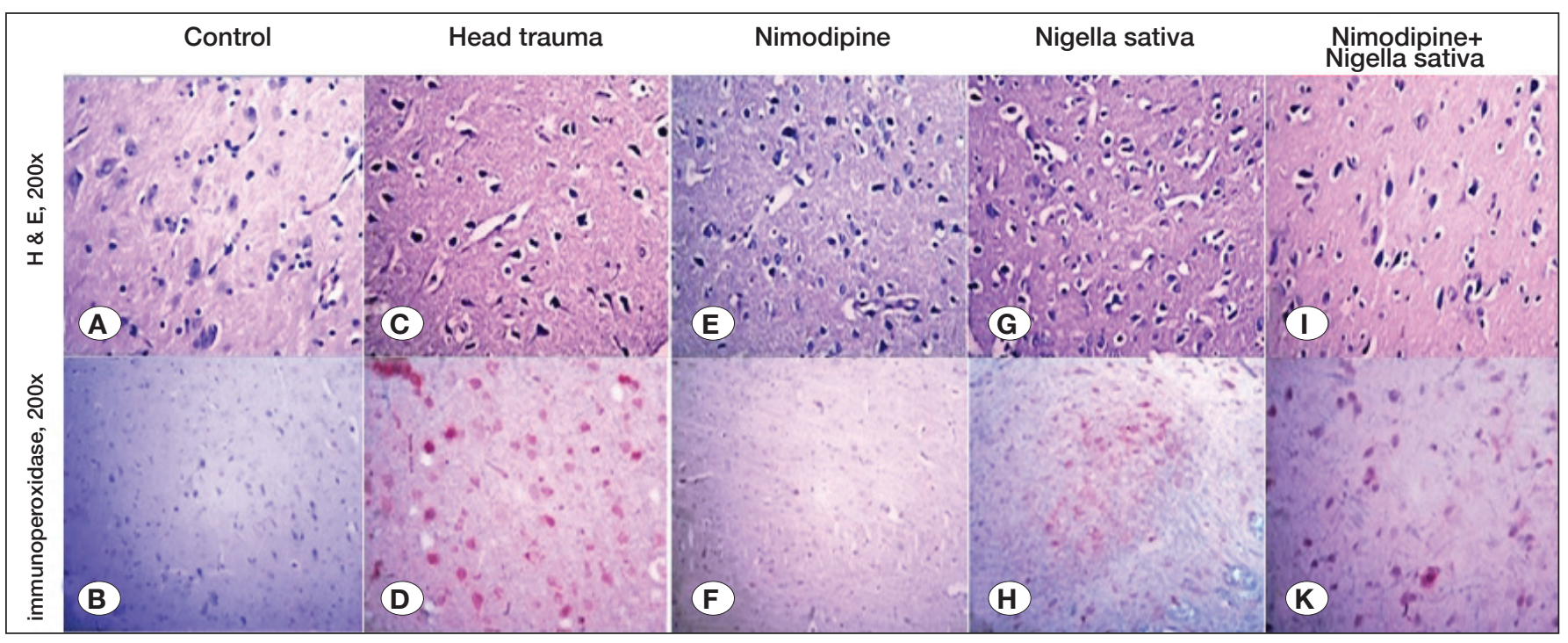

Figure 4: A) Normal brain tissue in a rat in the control group [Hematoxylin Eosin (HE), 200x]. B) In the control group, apoptotic cell is not observed in the caspase-3 staining of brain tissue (immunoperoxidase, 200x). C) Many traumatic cells are observed in head trauma group (HE, 200x). D) The head trauma group shows a large number of apoptotic cells stained with caspase-3 (immunoperoxidase, 200x). E) There are few degenerated cells in the Nigella Sativa group (HE, 200x). F) In the Nigella sativa group, a small number of apoptotic cells (immunoperoxidase, 200x) were observed in caspase-3 staining. G) Moderate degenerated cells in Nimodipine group (HE, 200x). H) In the nimodipine group, moderate apoptotic cell staining with caspase-3 is observed (immunoperoxidase, 200x). I) Nimodipine + Nigella sativa group has moderate degenerate cells (HE, 200x). K) In the nimodipine + Nigella sativa group, moderate apoptotic cell staining with caspase-3 is observed (immunoperoxidase, 200x).

brain tissue and serum were significantly lower than those in controls, and PON1 levels were higher than those in controls.

NS has been shown to exert protective effects against experimental ischemia reperfusion injury and has strong oxygen radical scavenging ability due to its antioxidant properties (35). NS inhibits diabetic experimental neuropathy, decreases oxidative stress, protects against brainstem and frontal cortex damage due to chronic toluene use, and protects dopaminergic neurons in an experimental Parkinson's disease model $(19,39)$. NS has been shown to reduce lipid peroxidation in the hippocampus after cerebral ischemia reperfusion injury (21). The antiepileptic and antioxidant effects of NS were also demonstrated in an experimental epilepsy model (22).

Kanter et al. demonstrated the neuroprotective effects of NS on experimental spinal cord injury (27). The antioxidant and neuroprotective effects of NS on brain trauma have not 
been investigated until now. In our study, we found that the levels of TAS in both the serum and tissue of NS and N+NS groups increased compared to those in the control group. Although no difference was found in serum TOS levels in NS-treated rats compared to the other groups, TOS levels were significantly decreased in brain tissue in NS treated rats compared to those in controls. MDA levels were reduced in the NS group compared to those in the control group. In addition, MDA levels in NS and N+NS groups were lower than those in the control group. SOD levels were reduced in NS and $\mathrm{N}+\mathrm{NS}$ groups compared to those in controls in both serum and tissue. Furthermore, serum PON1 levels were increased in $\mathrm{NS}$ and $\mathrm{N}+\mathrm{NS}$ groups compared to those in the control group.

Histopathologically, the number of apoptotic cells was statistically higher in all groups than in controls. Compared to the HT group, the number of apoptotic cells was significantly decreased in NS and N+NS groups. The number of apoptotic cells decreased significantly in the $\mathrm{N}+\mathrm{NS}$ group compared to the group that received NS alone. Compared with controls, there was a statistically significant increase in caspase-3 staining in all groups. We found a statistically significant decrease in caspase 3 reactivity in N, NS and N+NS groups compared to the CT group. In summary, we found that apoptosis and caspase 3 levels increased after histopathological head trauma, but this increase was attenuated by N, NS, and $\mathrm{N}+\mathrm{NS}$ administration.

\section{CONCLUSION}

$\mathrm{N}$ and, particularly, NS show efficacy in reducing oxidative stress and lipid peroxidation products in rats exposed to experimental head trauma. Furthermore, these agents prevented apoptosis in the brain after the induction of trauma. There are many studies on the protective effects of $\mathrm{N}$ in the context of head injury, but there are not sufficient data on NS. Therefore, further studies with larger samples sizes are needed. We hope that these substances, whose role in neuroprotection cannot be denied, will shed light on future studies.

\section{ACKNOWLEDGEMENTS}

This study was funded by Dicle University Scientific Research Projects (Decision no: 2010/1).

\section{REFERENCES}

1. Ansari MA, Joshi G, Huang $Q$, Opii WO, Abdul HM, Sultana $R$, Butterfield DA: In vivo administration of D609 leads to protection of subsequently isolated gerbil brain mitochondria subjected to in vitro oxidative stress induced by amyloid betapeptide and other oxidative stressors: Relevance to Alzheimer's disease and other oxidative stress-related neurodegenerative disorders. Free Radic Biol Med 41(11):1694-1703, 2006

2. Aslan A, Gurelik M, Cemek M, Goksel HM, Buyukokuroglu ME: Nimodipine can improve cerebral metabolism and outcome in patients with severe head trauma. Pharmacol res 59(2):120124, 2009
3. Biegon A, Fry PA, Paden CM, Alexandrovich A, Tsenter J, Shohami E: Dynamic changes in N-methyl-D-aspartate receptors after closed head injury in mice: Implications for treatment of neurological and cognitive deficits. Proc Natl Acad Sci U S A 101 (14):5117-5122, 2004

4. Chesnut RM, Marshall LF, Klauber MR, Blunt BA, Baldwin N, Eisenberg HM, Jane JA, Marmarou A, Foulkes MA: The role of secondary brain injury in determining outcome from severe head injury. J Neurotrauma 34(2):216-222, 1993

5. De la Monte S, Neely TR, Cannon J, Wands JR: Oxidative stress and hypoxia-like injury cause Alzheimer-type molecular abnormalities in central nervous system neurons. Cell Mol Life Sci 57(10):1471-1481, 2000

6. DeKosky ST, Taffe KM, Abrahamson EE, Dixon CE, Kochanek PM, Ikonomovic MD: Time course analysis of hippocampal nerve growth factor and antioxidant enzyme activity following lateral controlled cortical impact brain injury in the rat. $J$ Neurotrauma 21(5):491-500, 2004

7. Draper $\mathrm{H}$, Hadley $\mathrm{M}$ : Malondialdehyde determination as index of lipid Peroxidation. Methods Enzymol 186:421-431, 1990

8. Dringen R, Pawlowski PG, Hirrlinger J: Peroxide detoxification by brain cells. J Neurosci Res 79(1-2):157-165, 2005

9. Durrington $P$, Mackness $B$, Mackness $M$ : Paraoxonase and atherosclerosis. Arterioscler Thromb Vasc Biol 21(4):473480,2001

10. El Tahir KE, Ashour MM, Al-Harbi MM: The respiratory effects of the volatile oil of the black seed (Nigella sativa) in guinea-pigs: Elucidation of the mechanism (s) of action. Gen Pharmacol 24(5):1115-1122,1993

11. El-Kadi A, Kandil O: The black seed (Nigella sative) and immunity: Its effect on human $\mathrm{T}$ cell subset. Federation Proceedings 46:1222, 1987

12. Engle MR, Singh SP, Czernik PJ, Gaddy D, Montague DC, Ceci JD, Yang Y, Awasthi S, Awasthi YC, Zimniak P: Physiological role of mGSTA4-4, a glutathione S-transferase metabolizing 4-hydroxynonenal: Generation and analysis of mGsta4 null mouse. Toxicol Appl Pharmacol 194 (3):296-308, 2004

13. Erel O: A new automated colorimetric method for measuring total oxidant status. Clin Biochem 38(12):1103-1111, 2005

14. Erel O: A novel automated method to measure total antioxidant response against potent free radical reactions. Clin Biochem 37(2):112-119, 2004

15. Gaur V, Aggarwal A, Kumar A: Protective effect of naringin against ischemic reperfusion cerebral injury: Possible neurobehavioral, biochemical and cellular alterations in rat brain. Eur J Pharmacol 616(1-3):147-154, 2009

16. Guemouri L, Artur Y, Herbeth B, Jeandel C, Cuny G, Siest G: Biological variability of superoxide dismutase, glutathione peroxidase, and catalase in blood. Clin Chem 37(11):19321937, 1991

17. Guleş O, Ulker E: Methods for detection of apoptosis. YYÜ Veteriner Fakültesi Dergisi 19(2):73-78, 2008

18. Halliwell B: Antioxidant defence mechanisms from the beginning to the end (of the beginning). Free Radic Res 31(4):261-272, 1999 
Kamasak K. et al: Nimodipine, Nigella sativa and Head Trauma

19. Hamdy NM, Taha RA: Effects of Nigella sativa oil and thymoquinone on oxidative stress and neuropathy in streptozotocin-induced diabetic rats. Pharmacology 84 (3):127-134, 2009

20. Hanafy M, Hatem M: Studies on the antimicrobial activity of Nigella sativa seed (black cumin). J Ethnopharmacol 34(23):275-278, 1991

21. Hosseinzadeh H, Parvardeh S, AsI MN, Sadeghnia HR, Ziaee T: Effect of thymoquinone and Nigella sativa seeds oil on lipid peroxidation level during globalcerebral ischemia-reperfusion injury in rat hippocampus. Phytomedicine 14(9):621-627, 2007

22. Ilhan A, Gurel A, Armutcu F, Kamisli S, Iraz M: Antiepileptogenic and antioxidant effects of Nigella sativa oil against pentylenetetrazol-induced kindling in mice. Neuropharmacol 49(4):456-464, 2005

23. Kanter M: Protective effects of Nigella sativa on the neuronal injury in frontal cortex and brain stem after chronic toluene exposure. Neurochem Res 33(11):2241-2249, 2008

24. Kanter M, Coskun O, Budancamanak M: Hepatoprotective effects of Nigella sativa $L$ and Urtica dioica $L$ on lipid peroxidation, antioxidant enzyme systems and liver enzymes in carbon tetrachloride-treated rats. World J Gastroenterol 11(42):6684-6688, 2005

25. Kanter M, Coskun O, Kalayci M, Buyukbas S, Cagavi F: Neuroprotective effects of Nigella sativa on experimental spinal cord injury in rats. Hum Exp Toxicol 25(3):127-133, 2006

26. Kanter M, Coskun O, Korkmaz A, Oter S: Effects of Nigella sativa on oxidative stress and $\beta$-cell damage in streptozotocininduced diabetic rats. The anatomical record part A: discoveries in molecular, cellular, and evolutionary biology. Anat Rec A Discov Mol Cell Evol Biol 279(1):685-691, 2004

27. Kanter M, Coskun O, Uysal $\mathrm{H}$ : The antioxidative and antihistaminic effect of Nigella sativa and its major constituent, thymoquinone on ethanol-induced gastric mucosal damage. Arch Toxicol 80(4):217-224, 2006

28. Kanter M, Demir H, Karakaya C, Ozbek H: Gastroprotective activity of Nigella sativa $\mathrm{L}$ oil and its constituent, thymoquinone against acute alcohol-induced gastric mucosal injury in rats. World J Gastroenterol 11(42):6662-6666, 2005

29. Kanter M, Meral I, Yener Z, Ozbek H, Demir H: Partial regeneration/proliferation of the $\beta$-cells in the Islets of Langerhans by Nigella sativa L. in streptozotocin-induced diabetic rats. Tohoku J Exp Med 201(4):213-219, 2003

30. Kar Y, Sen N, Tekeli Y: Investigation of black cumin (Nigella sativa L.) seeds cultivated in region Samsun and country of Egypt in terms of antioxidant activity. SDÜ Fen Edebiyat Fak Fen Derg (E-Dergi) 2:197-203, 2007

31. Mahfouz $M$ : The isolation of a crystalline active principle from Nigella sativa L seeds. J Pharm Sci UAR 1:1-19, 1960

32. Marmarou A, Foda MAA-E, Brink Wvd, Campbell J, Kita H, Demetriadou K: A new model of diffuse brain injury in rats: Part I: Pathophysiology and biomechanics. J Neurotrauma 80(2):291-300, 1994

33. Marshall LF, Marshall SB, Klauber MR, Van Berkum Clark M, Eisenberg $\mathrm{H}$, Jane JA, Luerssen TG, Marmarou A, Foulkes MA: The diagnosis of head injury requires a classification based on computed axial tomography. J Neurotrauma 9:287-292, 1992
34. Matzilevich DA, Rall JM, Moore AN, Grill RJ, Dash PK: Highdensity microarray analysis of hippocampal gene expression following experimental brain injury. J Neurosci Res 67(5):646663, 2002

35. Mousavi S, Tayarani-Najaran Z, Asghari M, Sadeghnia $H$ : Protective effect of Nigella sativa extract and thymoquinone on serum/glucose deprivation-induced PC12 cells death. Cell Molneurobiol 30(4):591-598, 2010

36. Overbeeke R, Steffens-Nakken H, Vermes I, Reutelingsperger C, Haanen C: Early features of apoptosis detected by four different flow cytometry assays. Apoptosis 3(2):115-121, 1998

37. Ozdemir D, Uysal N, Gonenc S, Acikgoz O, Sonmez A, Topcu A, Ozdemir N, Duman M, Semin I, Ozkan H: Effect of melatonin on brain oxidative damage induced by traumatic brain injury in immature rats. Physiol Res 54(6):631-637, 2005

38. Ozturk E, Demirbilek S, But AK, Saricicek V, Gulec M, Akyol O, Ersoy MO: Antioxidant properties of propofol and erythropoietin after closed head injury in rats. Prog Neuropsychopharmacol Biol Psychiatry 29(6):922-927, 2005

39. Radad K, Moldzio R, Taha M, Rausch WD: Thymoquinone protects dopaminergic neurons against MPP+ and rotenone. Thymoquinone protects dopaminergic neurons against MPP+ and rotenone. Phytother Res 23(5):696-700, 2009

40. Shao C, Roberts KN, Markesbery WR, Scheff SW, Lovell MA: Oxidative stress in head trauma in aging. Free Radic Biol Med 41(1):77-85, 2006

41. Solaroglu I, Okutan O, Kaptanoglu E, Beskonakli E, Kilinc K: Increased xanthine oxidase activity after traumatic brain injury in rats. J Clin Neurosci 12(3):273-275, 2005

42. Sullivan PG, Keller JN, Mattson MP, Scheff SW: Traumatic brain injury alters synaptic homeostasis: Implications for impaired mitochondrial and transport function. J Neurotrauma 15(10):789-798, 1998

43. Travmas DK: The protective effects of propofol and citicoline combination in experimental head injury in rats. Turk Neurosurg 20(1):57-62, 2010

44. Tsikas D: Assessment of lipid peroxidation by measuring malondialdehyde (MDA) and relatives in biological samples: Analytical and biological challenges. Anal Biochem 524:1330,2017

45. Ustun M, Gurbilek M, Ak A, Vatansev H, Duman A: Effects of magnesium sulfate on tissue lactate and malondialdehyde levels in experimental head trauma. Intensive Care Med 27(1):264-268, 2001

46. Yurdakoc A, Gunday I, Memis D: Effects of halothane, isoflurane, and sevoflurane on lipid peroxidation following experimental closed head trauma in rats. Acta Anaesthesiol Scand 52(5):658-663, 2008

47. Zaoui A, Cherrah Y, Lacaille-Dubois M, Settaf A, Amarouch H, Hassar M: Diuretic and hypotensive effects of Nigella sativa in the spontaneously hypertensive rat. Therapie 55(3):379-382, 2000 